\title{
The dichotomy between protection and logging of the Endangered and valuable timber species Amburana cearensis in north-west Argentina
}

\author{
Natalia Politi, Luis Rivera, Leónidas Lizárraga, Malcolm Hunter, Jr \\ and Guillermo E. DeFossé
}

\begin{abstract}
Amburana cearensis is a commercially valuable timber species, categorized as Endangered on the IUCN Red List. It is distributed throughout the seasonal dry tropical forests of Brazil, Paraguay, Bolivia, Peru and Argentina. In Argentina it is restricted to the provinces of Salta, where legislation sets a minimum cutting diameter of $60 \mathrm{~cm}$, and Jujuy, where logging of this species has been banned since 1972. The effect of these laws on the species' conservation status has not been assessed. We estimated species density, using distance sampling methodology, and measured the diameter at breast height of each individual encountered at 13 sites in north-west Argentina. Across both provinces we found a density of 1.12 individuals $\mathrm{ha}^{-1}$ (95\% CI $0.48-2.63$ ) and there was no significant difference between the density in Salta $\left(5.15 \mathrm{ha}^{-1}\right.$; $\left.95 \% \mathrm{CI} 3.14-8.45\right)$ and that in Jujuy (3.67 ha $\mathrm{ha}^{-1}$; $95 \%$ CI $2.59-5.17$ ), although $84 \%$ of the individuals encountered in Salta were found at one site. Diameter at breast height was significantly lower in Salta than in Jujuy $(23 \pm 12$ vs $41 \pm 18 \mathrm{~cm} ; \mathrm{P}<0.05)$. These differences in the demography of the species between the provinces may be attributable to the application of different legislation. Our results indicate that it would be prudent to halt logging of this species in Salta until further information is gathered and a sustainable management plan developed.
\end{abstract}

Keywords Amburana cearensis, CITES, conservation status, density, IUCN Red List, minimum cutting diameter, population structure, sustainable forest management

NAtalia Politi (Corresponding author) and Luis Rivera Cátedra de Desarrollo Sustentable y Biodiversidad, Facultad de Ciencias Agrarias, Universidad Nacional de Jujuy, CONICET Jujuy, Argentina. E-mail natalia.politi@ fulbrightmail.org

LeONIDAS LizARRAGa Delegación Regional Noroeste, Administración de Parques Nacionales, Salta Capital, Argentina

MaLcolm HUNTER, JR, Department of Wildlife Ecology, University of Maine, Orono, USA

Guillermo E. Defossé Centro de Investigación y Extensión Forestal Andino Patagónico (CIEFAP-CONICET), Universidad Nacional de la Patagonia San Juan Bosco, Chubut, Argentina

Received 16 November 2012. Revision requested 7 January 2013.

Accepted 4 March 2013. First published online 19 February 2014.

\section{Introduction}

The lack of scientific information on the ecology and L biology of valuable tropical tree species impairs the development of adequate legislation and management guidelines for ecologically sustainable forestry (Mostacedo \& Rumiz, 2010). A common argument for continuing to log tropical forests is that if native forests do not provide an economic alternative they are more likely to be cleared for agriculture or plantations (Merry et al., 2009). Such arguments are based on the assumption that appropriate laws and regulations guide management (Shearman et al., 2012). However, enacting legislation does not improve forest management unless the laws are enforced. This is a problem given that it is estimated that $40 \%$ of the world's tree species are threatened with extinction (Oldfield et al., 1998; Newton \& Oldfield, 2008). Therefore assessment of the conservation status of threatened tree species is a priority for designing appropriate conservation plans and policies (López-Toledo et al., 2011), particularly as the portion of natural tropical forest area under timber production has increased steadily over time (Guariguata et al., 2012). Despite the increase in sustainable forest management plans throughout the tropics (ITTO, 1990; Poore \& Sayer, 1991) an estimated $127,300 \mathrm{~km}^{2}$ of tropical forest is lost annually (FAO, 1999). Over 90\% of tropical forests are managed unsustainably (Blaser et al., 2011) and only a small percentage of the total area of tropical forest is under certified sustainable management (Bowles et al., 1998).

Amburana cearensis (Fr. Allem.) A.C. Smith (South American oak, known locally as roble) is a Neotropical tree species of the family Fabaceae, subfamily Papilionoidea, with a geographical range covering the seasonal dry tropical forests and transition zones of Brazil, Paraguay, Bolivia, Peru and Argentina (Dimitri, 1997). This region constitutes a phytogeographical entity: Seasonally Dry Tropical Forests of the Pleistocenic Arc (Prado, 2000). Although A. cearensis has high economic value and is categorized as Endangered on the IUCN Red List there has been no effort to delineate a conservation and management plan for the species (Leite, 2005; Americas Regional Workshop, 1998). The species' distribution, population structure and regeneration pattern are poorly documented, making it difficult to develop management guidelines (Osinaga Eguez, 1997). A. cearensis attains large dimensions: $15-25 \mathrm{~m}$ height and $40-110 \mathrm{~cm}$ diameter at breast height (DBH; López et al., 1987) and has 
a moderate growth rate $\left(0.89 \mathrm{~cm} \mathrm{year}^{-1}\right.$ in diameter), although initial growth is slow (Calzon \& Palma, 2008). It starts reproducing when $\mathrm{DBH}$ reaches $>60 \mathrm{~cm} ; 90 \%$ of individuals attain reproductive age when they reach $\mathrm{DBH}$ $>67 \mathrm{~cm}$ (van Rheenen, 2005; Ayarde, 2006). The species bears seeds every 3-4 years, during September-October (Ayarde, 2006). Ripe seeds are dispersed from the open legume and lose viability quickly (López et al., 1987).

In Argentina $A$. cearensis is restricted to the provinces of Salta and Jujuy, in a narrow belt (400-750 m altitude) of the Sub-Andean Piedmont Forest (Prado, 2000). This forest harbours a high number of species (e.g. 300 woody species, of which 113 are trees, 39 amphibians, 137 birds, and 106 mammals) and is the most threatened forest ecosystem of Argentina (Brown et al., 2006). Analysis indicates that the remaining area of piedmont forest is $<37 \%$ of its original cover, and most of the remaining stands are confined to steep and less accessible areas (Brown et al., 2009). The remaining piedmont forests are degraded and almost all stands have been affected by logging (Brown et al., 2002), in which harvesting is focused on a few valuable timber species, with virtually no inventory or planning. Forestry statistics show a decreasing trend overall in timber volume of all species harvested and a concomitant increase in the area logged, probably associated with a depleted timber stock (Eliano et al., 2009).

Unplanned and extractive logging in the piedmont forest has compromised most valuable timber species, including A. cearensis. In the province of Salta the decrease in the number of individuals of $A$. cearensis prompted a 1960 decree (No. 15.742/1960) restricting logging to individuals of $>60 \mathrm{~cm} \mathrm{DBH}$ (minimum legal cutting diameter). In Jujuy province logging of the species was banned in 1972 (Decree No. 676-H-72). The mismatch between legislation in these neighbouring provinces and the lack of control has made law enforcement difficult. Furthermore, forest management plans do not prioritize the protection of this valuable resource. For these reasons information about the status of this species is needed. We analysed the size and structure of the population of $A$. cearensis in the two provinces, to assess whether different legislation has influenced the conservation status of the species.

\section{Study area}

The study was conducted in the Sub-Andean Piedmont Forest of the Upper Bermejo River in north-west Argentina (Fig. 1). The forest covers c. 900,000 ha $(80 \%$ steep terrain and $20 \%$ flat terrain; Brown et al., 2009). Annual rainfall is variable $(800-1,000 \mathrm{~mm})$, with a pronounced dry season during March-November; Bianchi et al., 2008). Mean annual temperature is $18-20^{\circ} \mathrm{C}$, with peaks of $>40{ }^{\circ} \mathrm{C}$ in the summer (Bianchi et al., 2008). Mature piedmont forest stands in north-west Argentina have a continuous canopy
25-35 $\mathrm{m}$ in height, a basal area of $25-30 \mathrm{~m}^{2} \mathrm{ha}^{-1}$ and c. 35-40 tree species ha ${ }^{-1}$ (Brown \& Malizia, 2004). They also have thorny shrubs and a number of xerophytic elements (Prado, 1995).

\section{Methods}

We surveyed, using distance sampling (Buckland et al., 2001), at 13 sites (five in Jujuy and eight in Salta; Table 1; Fig. 1) in areas where the species could be present based on its potential distribution in north-west Argentina, an area of $1,732 \mathrm{~km}^{2}$ (Malizia et al., 2009). Distance sampling methodology is more appropriate than conventional sampling methods for estimating the density of rare species that are sparsely distributed across large geographical areas (Cochran, 1977; Buckland et al., 2001). From May 2007 to May 2008 we established $20100 \mathrm{~m}$ transects of variable width at each site to detect individuals of $A$. cearensis. Its characteristic bark makes the species particularly easy to detect. When an A. cearensis tree was detected we measured the perpendicular distance from the transect line to the tree, using a metric tape. The $\mathrm{DBH}$ of each individual was measured $1.3 \mathrm{~m}$ above ground, using a metric tape. We conducted a more detailed survey from October 2010 to October 2011, covering 70 ha at Finca Río Seco (in Salta province), owned by the forestry company Forestal Santa Bárbara, and 72 ha at Finca Yuchán (in Jujuy province), owned by the agribusiness firm Ledesma. To our knowledge these stands represent the best piedmont forest in northwest Argentina.

We used Distance v. 5.0 (Thomas et al., 2006) for data analysis at two levels: province (Jujuy and Salta) and country (i.e. both provinces together). For each province we estimated density in three diameter size classes. Detection functions were selected based on Akaike's information criterion (Burnham \& Anderson, 1998), $\chi^{2}$ model fit statics and visual inspection of detection probability and probability density plots (Buckland et al., 2001). Grouped cut points and truncation distances were used to remove outliers from the analysis.

\section{Results}

A total of 813 individuals of $A$. cearensis were detected in 1,114 ha of the area surveyed in both provinces, yielding an estimated density of $1.12 \mathrm{ha}^{-1}$ (95\% CI $0.48-2.63$ ). There was no significant difference between the density of the species in Salta (5.15 ha ${ }^{-1}$; 95\% CI 3.14-8.45) and that in Jujuy (3.67 ha ${ }^{-1}$; 95\% CI 2.59-5.17) although DBH was significantly lower in Salta $(23 \pm$ SD 12 vs $41 \pm$ SD $18 \mathrm{~cm} ; \mathrm{P}<0.05)$. Density estimates decreased consistently with increasing DBH class, approximating a reverse J-shape (Fig. 2). The density of stems in the ${ }^{-20} \mathrm{~cm}$ DBH class was greater in Salta than in Jujuy and the density of stems in the $>40 \mathrm{~cm} \mathrm{DBH}$ class was lower 
TABLE 1 Details of sites surveyed for Amburana cearensis in the provinces of Jujuy (where harvesting is banned) and Salta (where harvesting is permitted), Argentina (Fig. 1) during 2007-2008.

\begin{tabular}{llcl}
\hline Site & Altitude (m) & Area surveyed (ha) & Management $^{1}$ \\
\hline Jujuy province & & & \\
Fraile Pintado & 700 & 82 & CTL \\
Rio Colorado & 588 & 85 & CTL \\
Finca Yuchán & 663 & 96 & NL \\
Calilegua National Park & 519 & 198 & NL \\
Calilegua National Park Northern Sector & 710 & 75 & NL \\
Salta province & & & FSC \\
Pintascayo & 699 & 74 & CTL \\
Piquirenda & 607 & 34 & CTL \\
Acambuco Provincial Reserve and Buffer Zone & 862 & 98 & CTL \\
Río Seco (Finca Flores) & 568 & 73 & CTL \\
Embarcación & 312 & 54 & FSC \\
Finca Río Seco (Forestal Santa Bárbara) & & \\
Surroundings of Tabacal & 535 & 82 & CTL \\
Valle Morado & 393 & 96 & CTL \\
\hline
\end{tabular}

${ }^{1}$ CTL, conventional timber logging; FSC, Forest Stewardship Council certification; NL, no logging since 1979

${ }^{2}$ Harvesting banned by the Forest Stewardship Council in 2008, pending the development of a management plan for the species

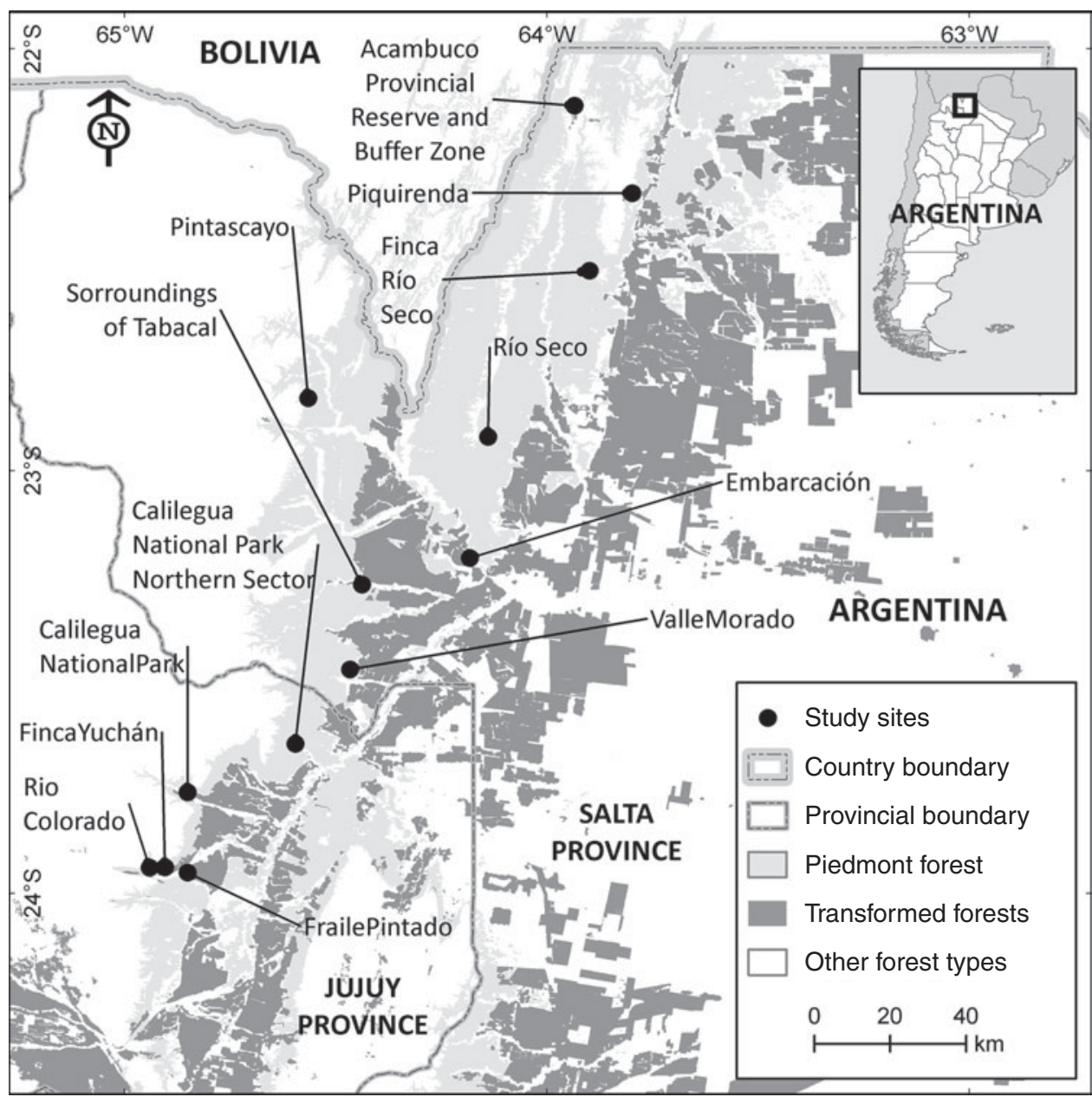

FIG. 1 Location of study sites (Table 1) in the piedmont forest of north-west Argentina. The rectangle on the inset indicates the location of the main map in Argentina. 


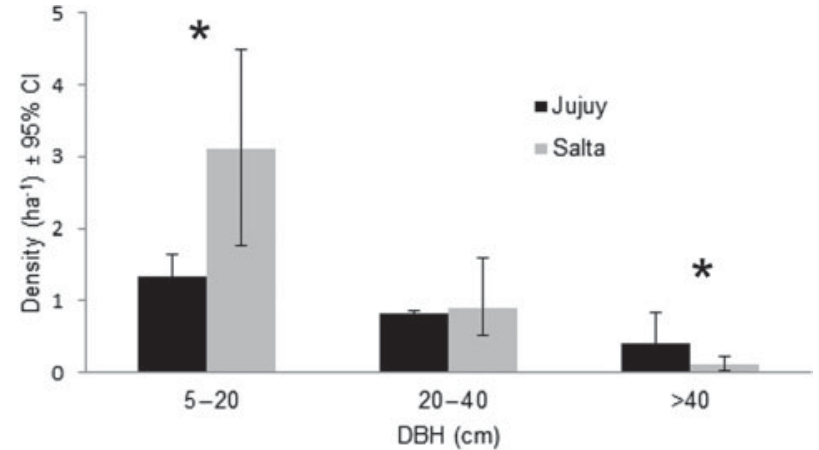

FIG. 2 Density (with 95\% CI) estimates for Amburana cearensis, using distance sampling methodology based on diameter class distribution, in Jujuy and Salta provinces in Argentina (Fig. 1). An asterisk $\left.{ }^{*}\right)$ indicates significant differences between provinces for a given diameter class.

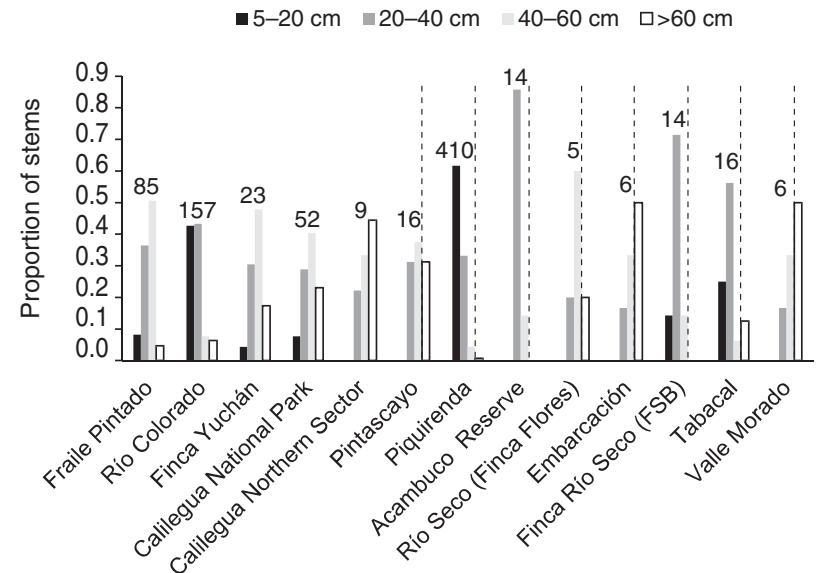

FIg. 3 Proportion of individuals of $A$. cearensis detected in each diameter size class $(5-20 ; 20-40 ; 40-60 ;>60 \mathrm{~cm} \mathrm{DBH})$ at each site surveyed. The dashed line indicates the legal cutting limit in Salta. The numbers above the bars indicate the number of individuals detected at each site.

in Salta than in Jujuy (Fig. 2). Most individuals (84\%) encountered in Salta were found at one site (Piquirenda), which had a high proportion of individuals in the lower diameter classes (Fig. 3). Most sites (60\%) had a bell-shaped distribution of diameter class (Fig. 3). The detailed diameterclass distribution in Finca Yuchán and Finca Río Seco also showed a bell-shape (Fig. 4). The density of the species was $1.5 \mathrm{ha}^{-1}$ in Finca Yuchán and $0.4 \mathrm{ha}^{-1}$ Finca Río Seco; there was no significant difference in $\mathrm{DBH}$ at the two sites $(44.23 \pm 17.49 \mathrm{~cm}$ vs $47.02 \pm 14.17 \mathrm{~cm} ; \mathrm{P}=0.20)$.

\section{Discussion}

Our data show differences in the characteristics of the populations of $A$. cearensis in the two provinces that may be attributable to the application of different legislation.

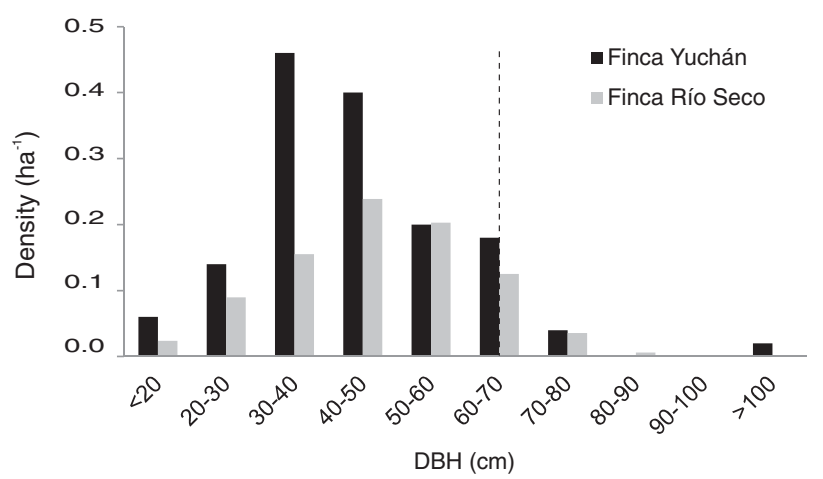

FIG. 4 Density of $A$. cearensis detected in Yuchán, Jujuy province and Finca Río Seco, Salta province, according to the diameter size class distribution. The dashed line indicates the legal cutting limit in Salta.

Nevertheless, although legislation in Jujuy has probably prevented further decline of the species there, it has not been accompanied by incentives to encourage research on the species. Conventional unsustainable timber management in Salta province appears to be having a negative effect on the population structure (there is a low density of individuals $>60 \mathrm{~cm} \mathrm{DBH}$ ). Sustainable use and trade in timber have been proposed as an economic incentive for forest conservation (Putz et al., 2001; Pearce et al., 2003; Newton, 2008) but the conservation-through-use argument requires that technical uncertainties, including lack of appropriate ecological information, are overcome (Dickinson et al., 1996; Newton, 2008). For example, to make appropriate decisions regarding effective silvicultural treatments for $A$. cearensis the reproductive biology of the species (Leite, 2005) must be understood. If logging continues in Salta province the species will probably decline further, leading to its economic extinction in this part of Argentina.

A. cearensis was categorized as Endangered on the IUCN Red List in 1998 but its status requires updating (IUCN, 2013). To identify regional bias as a result of population differences it is necessary to conduct national categorizations and integrate those regional assessments to determine the species' current status globally (Gárdenfors et al., 2001). Our results suggest that the categorization as Endangered is correct for Argentina, where the species has a low density. Previous stand-scale forest inventory surveys in Argentina also reported that $A$. cearensis has a low density (Ayarde, 2006; Malizia et al., 2009) and it was assumed that the species was rare historically (Calzón \& Palma, 2008). The species is threatened by deforestation of the piedmont forest of north-west Argentina for agricultural and urban development (Eliano et al., 2010). Superimposed on this threat is the high logging pressure (Quiroga \& Salinas, 1996), which decreases the density of the species, impairs its natural regeneration and could lead to local extinction (Fredericksen \& Putz, 2003). In our study the low 
proportion of stems that occur in the $>60 \mathrm{~cm} \mathrm{DBH}$ class (i.e. the class at which the species starts reproducing) in Salta is an indication of the logging pressure on the species. The populations of $A$. cearensis in Finca Yuchán and Finca Río Seco were dominated by individuals of the intermediate size classes, with few individuals in the small and mature size classes. A similar bell-shaped distribution has also been reported from studies of $A$. cearensis in Bolivia, where most individuals were concentrated in the $30-50 \mathrm{~cm} \mathrm{DBH}$ class (Osinaga Eguez, 1997). However, the Finca Yuchán population structure was skewed more to the left and had higher density in all diameter size classes compared to Finca Río Seco, which may indicate that the ban on harvesting in Jujuy has reduced pressure on the A. cearensis population in Finca Yuchán.

Conservation management must encompass social, economic and political trade-offs to reach practical solutions (Newton, 2007). In the absence of reliable scientific information on which to base management decisions it is wise to employ multiple strategies. We make the following recommendations for the conservation of $A$. cearensis in Argentina. (1) Incorporate areas that contain the largest populations and best age structure (i.e. those with a broad range of diameter classes represented) into the regional protected area network. Finca Yuchán, Fraile Pintado, and Rio Colorado are priority areas for conservation because the largest populations, with the best age structure, are found here (only $1 \%$ of the piedmont forest is currently under any legal protection; Brown et al., 2002). (2) Reinforce the population to facilitate natural regeneration (Doucet et al., 2009); this will probably require using nursery-sourced seedlings and, in the absence of genetic research, it is essential to ensure that these seedlings come from local seed stocks. (3) Develop the support and cooperation of a broad array of stakeholders (governmental policy-makers, NGOs, landowners, local citizen representatives and scientists) for restoration, conservation planning and protection of the species. (4) Legislate to protect remnant individuals of the species during land conversion, to conserve the genetic diversity of the species (Hamrick et al., 1992; Manning et al., 2006).

Improved knowledge of the ecology of A. cearensis is required (Hutton \& Leader-Williams, 2003) before logging can be allowed in Jujuy province or continued in Salta province. Stringent forest management standards, such as forest certification criteria, provide an opportunity to develop management and conservation plans for threatened species (SmartWood, 2005). This strategy is currently being followed by the Forestal Santa Bárbara forestry company, which adheres to the principles and criteria of the Forest Stewardship Council. This company halted logging of A. cearensis in 2008 and has promoted research to develop a species conservation action plan (Forestal Santa Bárbara, 2011). Listing A. cearensis in Appendix I of CITES could restrict its international trade but could also inhibit the emergence of sustainable management practices and result in conversion of $A$. cearensis habitat to agriculture because of a lack of economic alternatives (Turner et al., 2001). In contrast, listing A. cearensis in CITES Appendix II, accompanied by management guidelines based on knowledge of the species' ecology and high forest management standards, could help promote improved management for timber exploitation and international trade. For example, forest management guidelines for the species should include a minimum cutting diameter of $90 \mathrm{~cm} \mathrm{DBH}$ and retain $70 \%$ of the individuals recorded in forest inventories to ensure stems of medium-size diameter classes as seed sources for future regeneration. In Argentina management standards can be framed and supported by the National Forest Conservation Law (26.331), which has established a fund to promote restoration of degraded stands and develop sustainable forest management.

We have provided evidence that the approach to logging established in Salta province is not ensuring the conservation of A. cearensis. It is imperative that the status of this species be assessed and appropriate legislation and management be enacted, based on the species' ecology and biology (Schulze et al., 2008). We have passed our recommendations to the relevant decision-makers but they have not adopted them in management plans and forestry regulations. Therefore, we have begun an outreach programme to promote stakeholder involvement to implement silvicultural procedures for sound forest management. We are also conducting further research to determine the reproductive ecology and establishment requirements of this threatened and valuable timber species to refine our silvicultural prescriptions.

\section{Acknowledgements}

We are grateful to Diego Regondi, Pamela Fierro, Roque Yapura, Sebastían Albanesi, Patricia Puechagut, Marisol Mata, Ana Magdalena Gutierrez and Ramiro Carrillo for field assistance, and to Ledesma SAAI and Forestal Santa Bárbara SRL, the National Park Administration and the Environmental Ministries of Salta and Jujuy for granting the permits to conduct the study. The project was funded by Agencia Nacional de Promoción Científica y Tecnológica (PICT 2008-1165, Préstamo BID), Conservation Leadership Programme, Mohamed bin Zayed Species Conservation Fund, Forestal Santa Bárbara SRL and Idea Wild.

\section{References}

Americas Regional Workshop (Conservation \& Sustainable Management of Trees, Costa Rica, November 1996) (1998) Amburana cearensis. In IUCN Red List of Threatened Species v. 2013.1. Http://www.iucnredlist.org [accessed 20 November 2013]. 
Ayarde, H.R. (2006) Germinación y viabilidad de semillas de Amburana cearensis (Fabaceae). Lilloa, 43, 23-28.

Bianchi, A.R., Elena, H. \& Volante, J. (2008) SIG climático del NOA. INTA, Salta, Argentina.

Blaser, J., Sarre, A., Poore, D. \& Johnson, S. (2011) Status of Tropical Forest Management 2011. ITTO Technical Series 38. International Tropical Timber Organization, Yokohama, Japan.

Bowles, I., Rice, R.E., Mittermeier, R. \& Da Fonseca, A. (1998) Logging and tropical forest conservation. Science, 280, 1899-1900.

Brown, A.D., Blendinger, P. \& Lomáscolo, T. (eds) (2009) Ecología, historia natural y conservación de la Selva Pedemontana de las Yungas Australes. Ediciones del Subtrópico, Fundación ProYungas, San Miguel de Tucumán, Argentina.

Brown, A.D., Grau, A., Lomáscolo, T. \& Gasparri, N. (2002) Una estrategia de conservación para las selvas subtropicales de montaña (Yungas) de Argentina. Ecotrópicos, 15, 147-159.

Brown, A.D. \& Malizia, L.R. (2004) Las selvas pedemontanas de las Yungas: en el umbral de la extinción. Ciencia Hoy, 14, 52-63.

Brown, A.D., Pacheco, S., Lomáscolo, T. \& Malizia, L. (2006) Situación ambiental en los bosques andinos yungueños. In $\mathrm{La}$ Situación Ambiental Argentina 2005 (eds A.D. Brown, U. Martínez Ortiz, M. Acerbi \& J. Corchera), pp. 53-71. Fundación Vida Silvestre Argentina, Buenos Aires, Argentina.

Buckland, S.T., Anderson, D.R., Burnham, K.P., LaAke, J.L., Borchers, D.L. \& Thomas, L. (2001) Introduction to Distance Sampling: Estimating Abundance of Biological Populations. Oxford University Press, New York, USA.

Burnham, K.P. \& Anderson, D.R. (1998) Model Selection and Inference. Springer-Verlag, New York, USA.

Calzón, M.E. \& PAlma, R.M. (2008) El roble criollo. XXIII Jornadas Forestales de Entre Rios, Octubre 2008. Concordia, Entre Ríos, Argentina.

Cochran, W.G. (1977) Sampling Techniques. John Wiley \& Sons, New York, USA.

Dickinson, M.B., Dickinson, J.C. \& Putz, F.E. (1996) Natural forest management as a conservation tool in the tropics: divergent views on possibilities and alternatives. Commonwealth Forestry Review, 75, 309-315.

Dimitri, M.J. (1997) El nuevo libro del árbol: especies forestales de la Argentina occidental. El Ateneo, Buenos Aires, Argentina.

Doucet, J-L., Kouadio, Y.L., Monticelli, D. \& Lejeune, P. (2009) Enrichment of logging gaps with moabi (Baillonella toxisperma Pierre) in a Central African rain forest. Forest Ecology and Management, 258, 2407-2415.

Eliano, G., Somma, D.J. \& Quintana, R. (2010) Análisis y evaluación del proceso de fragmentación de hábitat en un sector de Yungas Argentinas. Asociación Argentina de Ecología de Paisajes RASADEP, 1, 67-76.

Eliano, P.M., Badinier, C. \& Malizia, L.R. (2009) Manejo forestal sustentable en Yungas: protocolo para el desarrollo de un plan de manejo forestal e implementación en una finca piloto. Ediciones del Subtrópico, Fundación ProYungas, San Miguel de Tucumán, Argentina.

FAO (1999) Global Forest Resources Assessment. FAO Forestry Paper 140. Food and Agriculture Organization of the United Nations, Rome, Italy.

Forestal Santa Bárbara SRL (2011) Estrategia de Manejo y Monitoreo de Atributos de Alto Valor de Conservación. Unidad de Manejo Forestal Rio Seco. Forestal Santa Bárbara SRL, Salta, Argentina.

Fredericksen, T.S. \& Putz, F.R. (2003) Silvicultural intensification for tropical forest conservation. Biodiversity and Conservation, 12, $1445^{-1453}$.
Gárdenfors, U., Hilton-Taylor, C., Mace, G.M. \&

Rodriguez, J.P. (2001) The application of IUCN Red List criteria at regional levels. Conservation Biology, 15, 1206-1212.

Guariguata, M.R., Sist, P. \& Nasi, R. (2012) Multiple-use management of tropical production forests: how can we move from concept to reality? Forest Ecology and Management, 263, 170-174.

Hamrick, J.L., Godt, M.J.W. \& Sherman-Broyles, S.L. (1992) Factors influencing levels of genetic diversity in woody plant species. New Forests, 6, 95-124.

Hutton, J.M. \& Leader-Williams, N. (2003) Sustainable use and incentive-driven conservation: realigning human and conservation interests. Oryx, 37, 215-226.

iTTO (International Tropical Timber Organization) (1990) Guidelines for the Sustainable Management of Natural Tropical Forests. ITTO Policy Development Series No. 1. ITTO, Yokohama, Japan.

IUCN (2013) IUCN Red List of Threatened Species v. 2013.2. Http:// www.iucnredlist.org [accessed 5 December 2013].

Leite, E.J. (2005) State-of-knowledge on Amburana cearensis (Fr. Allem.) A.C. Smith (Leguminosae: Papilionoideae) for genetic conservation in Brazil. Journal for Nature Conservation, 13, 49-65.

López, J., Little, E.L., Ritz, G.F., Rombold, J.S. \& Hahn, W.J. (1987) Árboles comunes del Paraguay. Cuerpo de Paz, Washington, DC, USA.

López-Toledo, L., Gonzalez-Salazar, C., Burslem, D.F.R.P. \& Martinez-Ramos, M. (2011) Conservation assessment of Guaiacum sanctum and Guaiacum coulteri: historic distribution and future trends in Mexico. Biotropica, 43, 246-255.

Malizia, L.R., Pacheco, S.E. \& Loiselle, B.A. (2009) Árboles de valor forestal en las Yungas de la alta cuenca del río Bermejo. In Ecología, historia natural y conservación de la Selva Pedemontana de las Yungas Australes (eds A.D. Brown, P. Blendinger \& T. Lomáscolo), pp. 105-120. Ediciones del Subtrópico, Fundación ProYungas, San Miguel de Tucumán, Argentina.

Manning, A.D., Fischer, J. \& Lindenmayer, D.B. (2006) Scattered trees are keystone structures-implications for conservation. Biological Conservation, 132, 311-321.

Merry, F., Soares-Filho, B., Nepstad, D., Amacher, G. \& Rodrigues, H. (2009) Balancing conservation and economic sustainability: the future of the Amazon timber industry. Environmental Management, 44, 395-407.

Mostacedo, B. \& Rumiz, D. (2010) Estimación del estado de conservación de las especies maderables de la chiquitanía en Bolivia. Revista Boliviana de Ecología y Conservación Ambiental, 28, 43-52. Newton, A.C. (2007) Forest Ecology and Conservation: A Handbook of Techniques. Oxford University Press, Oxford, UK.

Newton, A.C. (2008) Conservation of tree species through sustainable use: how can it be achieved in practice? Oryx, 42, 195-205.

Newton, A.C. \& Oldfield, S. (2008) Red Listing the world's tree species: a review of recent progress. Endangered Species Research, 6, $137-147$.

Oldfield, S., Lusty, C. \& MacKniven, A. (1998) The World List of Threatened Trees. World Conservation Press, Cambridge, UK.

Osinaga Eguez, J.L. (1997) Análisis de la distribución espacial del roble (Amburana cearensis) y verdolago (Calycophyllum multiflurum) y su germinación en la comunidad de Lomerio, Santa Cruz. BSc thesis. Facultad de Ciencias Agrícolas, Universidad Autónoma Gabriel René Moreno, Santa Cruz, Bolivia.

Pearce, D., Putz, F.E. \& VAnClay, J.K. (2003) Sustainable forestry in the tropics: panacea or folly? Forest Ecology and Management, 172, 229-247.

Poore, D. \& SAyer, J. (1991) The Management of Tropical Moist Forest Lands: Ecological Guidelines. IUCN, Gland, Switzerland. 
PRADO, D. (1995) La selva pedemontana: contexto regional y lista florística de un ecosistema en peligro. In Investigación, Conservación y Desarrollo en las Selvas Subtropicales de Montaña (eds A.D. Brown \& H.R. Grau), pp. 19-52. Laboratorio de Investigaciones Ecológicas de las Yungas, Universidad Nacional de Tucumán, San Miguel de Tucumán, Argentina.

PRADO, D.E. (2000) Seasonally dry forests of tropical South America: from forgotten ecosystems to a new phytogeographic unit. Edinburgh Journal of Botany, 57, 437-461.

Putz, F.E., Blate, G.M. \& Redford, K.H. (2001) Tropical forest management and conservation of biodiversity: an overview. Conservation Biology, 15, 7-20.

Quiroga, M.S. \& Salinas, E. (1996) Minerales y madera: temas para el debate ambiental. Grupo de acción y reflexión sobre el medio ambiente. Fundación Heinrich-Boll, La Paz, Bolivia.

Schulze, M., Grogan, J., Landis, R.M. \& Vidal, E. (2008) How rare is too rare to harvest? Management challenges posed by timber species occurring at low densities in the Brazilian Amazon. Forest Ecology and Management, 256, 1443-1457.

Shearman, P., Bryan, J. \& Laurance, W.F. (2012) Are we approaching 'peak timber' in the tropics? Biological Conservation, $151,17-21$.

Smart Wood (2005) Estándares Genéricos de Rainforest Alliance/SmartWood para Evaluaciones de Manejo Forestal en Argentina. Unpublished guidelines. SmartWood, New York, USA.
Thomas, L., Laake, J.L., Strindberg, S., Marques, F.F.C., Buckland, S.T., Borchers, D.L. et al. (2006) Distance 5.o. Research Unit for Wildlife Population Assessment, University of St. Andrews, UK. Http://www.ruwpa.st-and.ac.uk/distance/ [accessed 18 August 2005].

Turner, B., Cortina, S., Foster, D., Geoghegan, J., Keys, E., Klepeis, P. et al. (2001) Deforestation in the southern Yucatán Peninsular region: an integrative approach. Forest Ecology and Management, 154, 353-370.

van Rheenen, H.M.P.J.B. (2005) The Role of Seed Trees and Seedling Regeneration for Species Maintenance in Logged-over Forests. PROMAB, Riberalta, Bolivia.

\section{Biographical sketches}

Natalia Politi is developing management guidelines for sustainable timber harvesting activities that ensure the conservation of biodiversity. LUIS RIVERA leads projects on threatened species and promotes regional conservation strategies for these species in northwest Argentina. LEÓNIDAS LIZARRAGA is a geographical information system specialist studying spatial-temporal human and ecological relationships between protected areas and their surroundings. Malcolm HUNTER JR studies the interface between maintaining biodiversity and managing ecosystems for natural resources. Guillermo E. Defossé's research focuses on the effect of fire on forests and grasslands, and ecological restoration of disturbed forest ecosystems. 